\title{
The Authority of Kyai Toward The Santri: A Review of Gender Construction at Pondok Pesantren
}

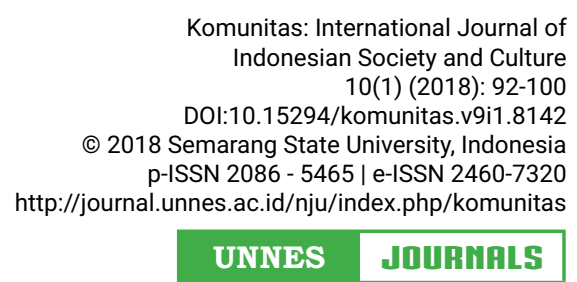

\section{Didi Pramono ${ }^{1}$}

${ }^{1}$ Sociology \& Anthropology Department, Faculty of Social Science, Universitas Negeri Semarang, Indonesia

Received: 6 December 2016; Accepted: 25 July 2017; Published: 30 March 2018

\begin{abstract}
The purpose of the study are assess the perception of Kyai and students about the gender construction, analyze the power of Kyai in forming gender construction, analyzing the social interactions between Kyai, students, and society. This study used a qualitative approach, with research location is in Al-Hikmah 2 Benda Boarding School Sirampog District, Brebes. Conclusions of the study are Kyai and students have moderate views on the construction of gender, but in practice it is still ambiguous because it could not distinguish between nature and gender. This perception creates stereotypes that lead to the injustices against women, including subordination, marginalization, and the double burden in terms of access, participation, control, and benefits. The construction of Gender in Islamic Boarding School can be reinforced by the the interpretation of holy book that called kitab kuning with the title Qurrotul Uyun,Uqud al-Lujjayn,Adabul Alim wal Muta'lim,Ta'lim Al-Muta'allim.In addition, the Kyai's character in the dialectical process of externalization, objectivization, and internalization also contributed to the construction of gender. The concept of karomah and barokah that attached to the Kyai's itself can increasingly makes Kyai as a central figure in the boarding school, so the students very respect (tadzkim) of him. In this case, can be formed a relationship pattern patron-client relationship between Kyai, students, and society further strengthen the position of Kyai as a significant other in the process of gender construction in boarding school.
\end{abstract}

\section{Keywords}

kyai; santri; gender construction

\section{INTRODUCTION}

Gender differences and sex will not cause problems as long as it does not cause gender inequalities. Gender, is something that is actually not a familiar thing for the society, but in the reality talking an opposite. Gender inequalities are still widely found in various areas of life, whether against men and especially against women.

One of the gender inequalities caused by the socialized of gender bias. Gender so- cialization can occur anywhere and by anyone. Various institutions and organization as well as family and religion also perpetuate gender concepts have not been fair and that socialized to the society or individual, therefore the concepts of gender socialization occur which has not been compensated

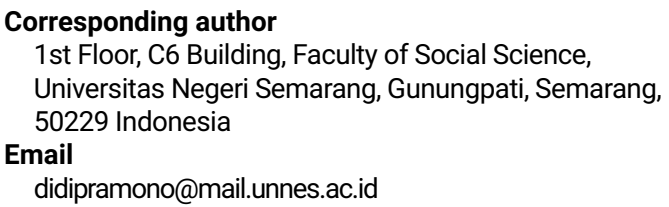


and equivalent. Socialization of gender belief committed by various media ends up being gender belief rooted in the mind of society/individual, so that will affect in personal action, families, groups, and societies, as well as the State. Socialization can occur in households, schools, teachers, society, religious figures and society figures, parents, press, and electronic media (Astuti 2011, p.11).

One of the agents of socialization of gender into focus in this study is an educational institution. The educational institution has a strategic role in gender socialaized. Gender socialization in school can be done through teaching and learning activities, extra-curricular activities, activities outside the classroom, textbooks, instructional media, and the elections Department. Agents of socialization of gender in educational institutions include the principal, stakeholders, employees, teachers, librarians, gardeners, security, seller in the cafeteria, and other school part.

The institutions in question include schools, madrasah, and boarding schools. The last institution will be the subject of this research. Pondok Pesantren were chosen because of its unique, in terms of learning activities and its daily activities, the concept of lodging of santri (students), and especially with the figure of a Kyai has a major role in the social dynamics in pondok pesantren.

The research of Dhofier (in the Marhumah 2011, p.174) published in 1983 entitled "Study of the Kyai's View of Life", focus on the position and role of Kyai life on development of socio-religious Pondok Pesantren. The results showed that Kyai appear as main character, fully supported by a network of kinship, intellectual, symbolic and the Kyai entwined from one generation to another generations (more commonly known by the term gus).

Dhofier opinion corroborated by Faridl (2007, p.239) which states that in Islamic society, Kyai is one of the elite that had a very distinguished position and influence on the development of the community. Kyai became one of the elite strategic in society due to its figure who have a wide and deep knowledge about Islam. Kyai, theologically also is seen as a figure of the heir to the prophets (waratsat al-anbiya). Kyai are not just a source of legitimacy from a variety of religious values, but also almost in all aspects of life. At this point we can see the Kyai strategic roles, particularly in the social and political aspects of life in Indonesia.

The legitimacy of Kyai certainly difference from the principal at the formal school. The principal has no charisma as strong as Kyai hegemony in social reality. Only the principal can effect on the outer part of an institution and a resource that is in it. The relationship between superior and subordinate only as a coworker relationship. Emotional aspects in relationships with principal teachers, employees, learners are less intertwined. This is added by the fact that the principal is a functional position only lasted for four years, and placed on the one school to another school.

Figure of Kyai needs to be examined through a theological background adhered. It is important to reveal the frame of the foundation of the structure of cognition. Kyai interpretations toward the Koran, Hadist, fiqh Islam are source for Religious discourse that will reproduce in the socialized at the Pondok Pesantren where Kyai are.

Aspects inherent in the Kyai - such as religious understanding, charisma, the structural position in the Pondok Pesantren, and social status - makes a Kyai has the authority to build a social construction. Social construction built by Kyai patriarchy, because it tends to Kyai patriarchy culture inherited from parents, society, and culture patriarchy of the Middle East. Cultural patriarchy the Middle East goes into the structure of cognition and perception of Kyai through books or through the direct experience of Kyai who had studied in the Middle East.

Patriarchy Middle Eastern culture is reflected in the following story. A prophet's friend named Saad Ibn Rabi Ibn Zayd Habibah wife slaps for a problem. Habibah was not received and the event to denounce her father. His father then went to complain to the Prophet. The Prophet decided that Ha- 
bibah were asked to respond. The Prophet decision reaped protests from men in Medina. The significance of this event is the Prophet has been taking into account and understands very well with the effect, i.e. here will be certainly horrendous society dominated by men (Fakih 2008, p.133).

Background the community patriarchy it also imposes against interpret The Koran, Al-Hadist, and Kitab Kuning. Astuti (2011, p.127-128) explained that some of the books that taught in the Pondok Pesantren seen still gender bias. This can be understood because the books created in construction of social patriarchies. The Arab community is very patriarchies - inevitably - give significant effects against the interpretation of religious texts. The texts are interpreted in such a way that it reflects the prevailing mental attitude, i.e. the view which justifies the domination of men toward women. The texts are interpreted are sociological-contextual patented became theological texts that are absolute.

Interpretation of religious texts a lot done in boarding schools, either in boarding schools of the old type (salafi), transitional, as well as in boarding a new type (khalafi or modern). Kyai, again it needs to be emphasized here, have a central role in the interpretation of religious texts. Results interpretation of religious texts is then planned to santriwan and santriwati as theological texts that are absolute.

Pesantren Al-Hikmah 2 Sirampog District Objects is a new type of Pondok Pesantren (khalafi or modern). This categorization is based on Division of the Pondok Pesantren type according to the Dhofier (2011, p.75-76), i.e. the old type of boarding school (classic) and a new type. The characteristics of new type boarding school are there public schools and madrasah, madrasah-the majority of the subjects developed instead of the classical Islamic books. Pondok Pesantren, such as Tebuireng and Rejoso is a Pondok Pesantren in Jombang new type, because it has opened the junior high, high school, and University. Pondok Pesantren is keeping the teaching of classical Islamic books, but the portions were inadequate because the num- ber of teachers is insufficient when compared to the growth of the pesantren which reached tripled from 1998 to 2010.

Modernity Pesantren Al-Hikmah 2 Benda leaves behind one question, does the modernity of the pesantren positively impact for gender equality efforts between santriwan and santriwati? This raises a lot of questions, about how the construction of gender culture is generated by patriarchy? How the perception of Kyai and students of gender construction in Pondok Pesantren? How Kyai's authority was instrumental in forming the construction of gender roles at santriwan and santriwati at Pondok Pesantren? What discourse developed by Kyai in shaping gender construction at Pondok Pesantren? How the discourse rolled out by Kyai construction in shaping gender roles at Pondok Pesantren? How social interaction between Kyai, students, and societies around Pondok Pesantren?

Kyai phenomenon in Pondok Pesantren, with all the various, as described above is interesting to further scrutinized in the study entitled "The Authority of Kyai Toward The Students: A Review of Gender Construction at Pondok Pesantren". The study unearthed in the formulation of the problem as follows:

- How the perception of Kyai and Students of gender construction in boarding schools?

- How the authority of Kyai was instrumental in shaping gender construction on santriwan and santriwati at boarding schools?

- How social interaction between students, Kyai and, societies around boarding schools?

\section{METHOD}

The approach that is used in this study is a qualitative approach. The phenomenon of gender construction in Pondok Pesantren is a socio-cultural phenomenon of the construction taking place in daily life, which is always evolving in accordance with the existing social context. The hypothesis that is formulated can just break when en- 
tering the field. Therefore, it takes a qualitative approach, which can adjust to the many phenomena that spontaneously appeared.

Research on the construction of gender in the Pondok Pesantren was conducted at boarding schools Al-Hikmah 2 Benda Subdistrict Brebes Sirampog Objects. This Pondok Pesantren is well-known in Central Java. The students come from Brebes, Central Java and West Java, also outside of Java, such as Sumatra, Kalimantan, and Sulawesi.

Primary data in this study sourced from Kyai and students. Secondary data is sourced from the Koran, Al-Hadist, Kitab Kuning, and other documents about Pondok Pesantren Al-Hikmah 2 Benda. The data collected through the techniques of observation, interviews, field notes, focus group discussion, and documentation. The validity of data was tested through the technique of triangulation with the utilization of the resource.

Methods of data analysis used in this study is a qualitative method, i.e. by way of working with data, organizing data, sort into a unit that can be managed, synthesized, search and find patterns, find what is important and what is learned, and decide what can be told to others (Bogdan and Biklen in Moleong 2004, p.254). The data obtained are then processed so that the retrieved information is useful, then analyzed. The data obtained were analyzed using three furrows of Milles (1992, p.16-19), the process of the reduction of the data, the presentation of the data and draw the conclusion.

\section{RESULTS AND DISCUSSION}

\section{The perception of Kyai and Santris of Gender Construction}

Kyai at Pondok Pesantren Al-Hikmah 2 Benda have moderate views on the concept of gender. Kyai allow girls to school, work, officer, but it does not mean Kyai loosening the values and norms in society. Female students may not be excessive and behave and willed equated entirely with men. There are things that should not be done, women in Islamic jurisprudence is called qad'iyah, like being a priest praying, khatib of Friday praying, chieftain and marriage guardian. Things that can be roled by a woman named ikhtilaf are a leader, Member of Parliament, subdistrict head (camat), and urban village head (kepala desa/lurah).

The curriculum and teaching methods adopted from Arabic culture are very traditional and deeply impact the ways of thinking of all santri (pesantren students) and kyai (pesantren leaders). Pesantren culture is still very patriarchal, for example, women students are subject to strict rules and women are regarded as sinful beings. In addition, women students are prepared to become pious wives for men, not leaders (Nurish 2011).

Islam honors and raises the degree of women. Umar (1999, p.13) adds that the Koran trying looked at women in the structure of gender equality with men. Muthali'in (2001, p.45) explained that the Koran is the Holy Book of the Islamic religions actually confers equal status between men and women in the normative sense. Allah almighty said that the noblest man at his side is the most pious (al-Hujurat: 13), and Almighty God exalted all beings, both men and women (al-Isra: 70). The glory reflected in equal rights between husband and wife or between men and women (al-Baqara: 228). Allah almighty also provides reward and a good life, and God Almighty give an equal chance for all creatures to enter into paradise for the believers, pious, and charitable saleh (an-Nisa: 124, an-Nahl: 97, Ali-Imran: 195, Al-Ahzab: 35 ', and Al-Ghafir, 40).

Kyai and students do not have strict restrictions between the gender concepts with nature, the view between the two is still mixed. Nature is described using a gender approach. Kyai and santri holds that the nature of man are sentient beings, strong, leader, has a legacy of more than women, and most parties acted as the subject. The nature of women is being put forward more feeling (heart), not rational, it is easy to cry, weak, parties are crimes by men, the party led by men, women are stabilized, companion, and a complement of men.

Kyai and perceptions of students is 
believed to be a truth and is the teaching of the Lord. This conviction resulted in students agreeing the gender construction that occurred at Pondok Pesantren. Muthali'in (2001, p.23) tells us that through the process of socialization, gender is finally considered the provisions of God, as if a biological in nature and cannot be changed anymore.

The explanation of Kyai and students' perspection about the nature and the concept of the ideal male and female very contrary to the opinion of the experts. Gender and the nature is an entirely different entity. Gender is an inherent in men as well as women who are socially or culturally (Fakih 2008, p.8). Nature is God's provision, is fixed and cannot be changed forever, apply universal, could not be exchanged because of the inherent in gender, and is the physical trait (Astuti, p.2011).

The perception of Kyai-students of gender construction creates stereotypes that gave birth to the injustice against women. Many women are stereotyped by gender in the construction of a boarding school. This Stereotype cause women are experiencing forms of gender inequalities, such as subordination, marginalization, and the double burden in terms of access, roles, controls, and the benefits obtained.

\section{Kyai's Authority in The Process of Gender Construction}

The society is a product of man, and man is a product of society. These two things take place in dialectics: thesis, antithesis, and synthesis. This dialectic simultaneously indicates that society was never as a final product, but as a process that is being formed (Berger and Luckmann 1990, p.72-73). Construction of gender santriwan and santriwati at Pondok Pesantren Al-Hikmah 2 Benda is a boarding tradition, in which the main character is decorated inside, by Berger and Luckman (1990, p.68-69 and 100) referred to as significant others (influential people). This is because a Kyai are the ones social status, occupied most of the special boarding school, has karomah and barokah and also has the historical meaning for the students.
Kyai, as an educated person, inherit the theology from Allah SWT through prophet so he called waratsat al-anbiya. Therefore it makes Kyai has great effect and authority for the students. The effect is, the students will very obedient, docile and relent to his Kyai. This attitude is stronger when there is a discourse in holy book "Adabul Alim wal Muta'lim" created by Hasyim Asyari and holy book "Ta'lim Al-Muta'allim" created by Syeikh Zarnuji.

Huda, Yusuf, and Jasmi (2016, p.4) in his article "Understanding Comprehensive Learning Requirements in the Light of alZarnūjī's Ta'lìm al-Muta'allim" explained that the Islamic ethics on learning emphasizes the responsibility of the students to their teacher in the course of the study. These ethics, therefore, emphasize that the students must accord the teacher, and generally, all those who possess knowledge, a maximum respect. Besides the above, what the students learn also has ethical implications. According to al-Zarnūjī, in designing a curriculum, the purpose is as well as the ethical aspects (i.e., its religious implications) should be carefully considered to ensure that they are in harmony with the principles of Islam.

Foucault (in Ritzer and Goodman, 2007, p.612) told that this phenomenon in the theory of "genealogy of power". Genealogy power discuss about how to control our self and the other by producting the knowledge. The knowledge resulted the power that make people as the subject and then command people with that knowlwdge.

Discourse about gender apllied by Kyai in our daily life in Islamic school through 3 moment dialectical, like externalization, objectification and internalization ( Berger and Luckman, 1990 ). Externalization is held in Period of Orientatation of student or we call in MOS in bahasa. Period of orientation as the time for student to adapted with the outside and recognize the environment to created the existence of their self. (Mursanto, in Muslich 2008, p.151). Habitual is the way to raise the value in Islamic school. Pierre Bourdieu ( 1984 ) called it with "habitus". Habitus (in Ritzer and Goodman 2007, 
p.522 ) is structured by bounce or cognitive that is used by actor to faced the problem of social. Habitus produced and is produced by social life. Habitus dialectica is externalization from externalization and externalization from internalization (Bourdieu, in Ritzer and Good man 2007, p.523).

Objectification is the result that we achieve whether bounce or physics from activity of eksternalization. One of the result from eksternalization is discourse about constructive gender, in this case still deviate gender. The construction of gender in Islamic school placed men as the subjet and woman as the object. Men has more power than woman.

Internalization occured to student through absorbing from objective to subjective so, the student have been affected by social construction. Students make the social values of the culture in the Islamic school and gender construction as the part of their self. The students are product of the social life through internalization. The students are constructed by the meaning that had been objectivicated. The meaning is from Al-Qur'an, Al-Hadist and holy book. The students not only know the meaning of that symbol but also practice it in all aspect of their life (Eriyanto in Muclish 2008, p.152).

The construction of gender in Islamis School conducted by social instrument (Berger and Luckman 1990, p.100); which consists of room builder, the Islamic school manager, builder board, and nurse assembly. The manager of the room consists of the senior student (the student XII grade of senior high school), the graduated from senior high school and the young teacher. The manager of the Islamic school consists of the student that study in Ma'had 'Ali in Islamic school Al-Hikmah 2 Benda.

The discourse delivered by Kyai at this time is not only through conventional channels, but has been very progressive in developing through the media. Islamic preachers have embraced new technology and new media to communicate with their followers and attract a younger audience (Muchtar and Ritchey 2014, p.360). The numbers of Indonesian Islamic leaders who use social media continue to increase, and not only among the younger generation: the huge success of smart phones (which provides low cost e-mail and internet access). Accessible to everyone (Muchtar and Ritchey, 2014, p.369).

Builder board consists of Dr. H. Munthoha Nasucha, M.Pd., Drs. H. Sulkhi Aziz, H. Itmamuddin Masruri, Syarofuddin Masruri, Nasyar Alamuddin Masruri, Imaduddin Masruri, Dr. H. Ahmad Sidiq, Hj. Zakqqiyatul Fitriyah Masruri, $\mathrm{Hj}$. Indana Zulfah Masruri, $\mathrm{Hj}$. Ismatul Masruri, and $\mathrm{Hj}$. Eri Arofah.

Nurse assembly consists of KH. Sholahudin Masruri, S.Pd.I., KH. Muhlas Hasyim, M.A., KH. M. Izuddin Masruri, KH. Dr. Ahmad Najib Afandi, MA., KH. Idzomuddin Masruri, dan Nyai Hj. Wiwi Mudzdalifah.

The power of affecting of each social instrument can be shortly illustrated in Figure 1.

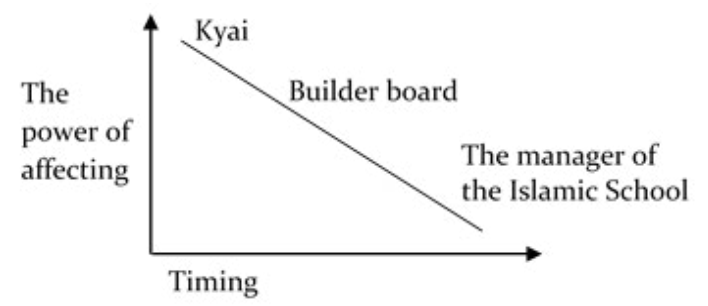

Figure 1. The degress of the affecting of social instrument

Figure 1 illustrated the power of the affecting the social instrument in Islamic school of Al-Hikmah 2 Benda. The manager of that school who often meet with the student, but the effect is small to all of the students. The manager meet with the students every day, they are the pioneer, in the first line, life together and build the positive communication. Kyai not often meet the students but the efffect is big.

The reconstruction has to exist when in practices the discourse of gender construction is occured. The three process social in build the reality of woman is construction, deconstruction, and reconstruction (Abdullah 2003, p.5). One of the most reveal in discussion about the position of man and woman is Surat An-Nisa ayat 34 tell "arrijalu qawwamuna ala nissa". Dzuhayatin (in 
Abdullah 2003, p.75) the meaning of word qawwam in Al-Qur'an should only related with the 'livelihood' family. Muslih (2004) mean that as a plea with the woman.

Nuriyah (2001) focused intrepretation of this verse in the problem of relationship between wife and husband, that the wife should do what the husband want because he is the leader. This obedience especially in problem of sex. The right to enjoy the sex is only for man not for woman. The implication, the man can force the woman to do sex with the man.

That assumption considered as the bad assumption and not fear, even it is disgress from the rule of religion (Khatimah 2013, p.237). Some of the ayat in Al-qur'an about woman should regard as the social background and the historical, textual and kontekstual (Astuti 2011, p.131).

Social interaction between Kyai, Santri, and the peolple in Islamic School.

The interaction between Kyai and student in Islamic school Al-Hikmah 2 Benda shaped the relationship pattern patronase, Kyai as the patron and the student as the client. This pattern as the effort to give the moral shelter to the student. Kyai teaches the knowledge to the students. Scoot (1972) say as the shelter because, through this knowledge the students will faced the problem of life now and the future. The shelter and safety from the Kyai also give by barokah from the Kyai . the student who get that barokah will live hapilly.

The realtionship about the patronclient between Kyai and the student is not fear, because, the differences of social state. Scoot (1972) said that one of caharacteristic of patron-client is the existence of not fearness. This is told by Scott as:

Disparity in their relative wealth, power and status. A client, in this sense, is someone who has entered an inequal exchange relation in which he is unable to reciprocate fully. A debt of obligation binds him the patron

A client in this case, is a person that included in exchange relationship which is unequal, student can't reply the goodness of Kyai fully. There is obligation debt of gra- titude that bend student to the Kyai. The students try to pay it off by serving themselves in form of their attitude, loyal, obedient, and submission. This imbalance made students have fear, shyness and regard attitude. A fear is feeling afraid, shyness is shame, and regard is feeling respect (Istiqomah et al 2014, p.7-8).

Further characteristics in patron client relationship are face to face, flexible, and extend. The interaction between student and Kyai can go on in formal, informal, and nonformal situation, in religion educational moment or even sharing about problems in daily life.

The patron client relationship between kyai and student in boarding school Al-Hikmah 2 Benda going on in long time, even lifetime. (Dhofier 2011, p.125). the tradition in boarding school uphold scientific sanad. A students will never end his studied, until they old or although until they become kyai.

The patron client relationship between Kyai and student are bilateral and mutualism symbiosis. Kyai play his role in both case, in front stage kyai play role as teacher religion and in back stage kyai play role as builder soul students. Kyai also serve guidance and counseling for their students who face problems in their live.

Interaction among kyai, student, and people can be drawn in this pattern below (Nafi' et al 2007).

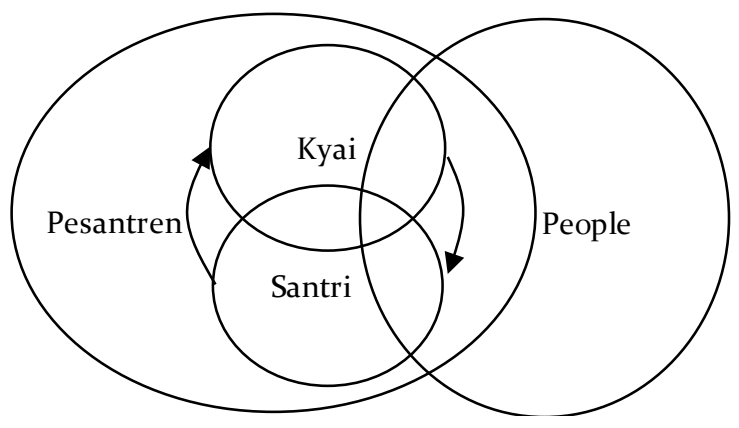

Figure 2. The Pattern of Interaction between Kyai, Santri, and People (Nafi' et al 2007)

The second figure illustrate about pattern interaction between Kyai, student, and 
people. The circle in left side is boarding school environment, in which consist of Kyai, students, and some people who live in boarding school environment. The people who are intended such as teachers, employees, sellers, gardeners, securities and other social roles. The circle in right side is people environment around boarding school.

Kyai, students, and people showed an interaction pattern which depending on each other. This case is indicated through the arrow direction which pointing at each component. Students need kyai in case of getting religion knowledge and favor in order to save life on earth and hereafter. Kyai also need students as next generation who will spread out Islamic knowledge and as indicator the fame of kyai. The students will left the degree of kyai. Students who have many achievements is the evidence of the successfulness of Kyai in theaching their students. Students also have economic value to boarding school and people.

People need kyai as teacher, companion, and knot learning. The existence of Kyai in among people is very needed to guide in the right way. People be intelligence because of the existence of boarding school, because not few students come from environment around boarding school. People also have mutual relation with students. Students empower people through BSK program. Students live up people economic and people serve goods and services which are needed by students.

\section{CONCLUSION}

Kyai and students have moderate view toward gender construction, however in real practice that view still confused, because both kyai and students cannot distinguish between fate concept and gender construction. Gender construction is believed as fate. This believed is strengthened by theological interpretation, so apparently as determination of God which can't be changed again. This perception kyai and students create stereotype that express unfairness regard to woman, such as subordination, marginalization, and double burden in case of access, role, control, and the advantage which is gotten.

Gender construction in boarding school is strengthened by figure of Kyai. Kyai has very big authority and influence in boarding school. Because kyai (a) is religious person; (b) occupied extraordinary social status in boarding school; (c) has karomah and barokah; (d) has historical value to boarding school environment. The authority of jyai made students loyal, submission and respect to all kyai's direction and command. Kyai is significant others in the process of dialedtical internalization, objectification, and internalization. In genealogy analysis authority, Kyai is person who produce and discourse gender construction. One thing that is regrettable is gender construction in boarding school more likely gender refraction, which is more sturdied by habitus, environment of boarding school, and theological interpretation. Reconstruction be one of necessity when the construction is more likely refraction gender. Reinterpretation upon exclamation of religion insists to do, and the woman's participation must be progressively improved in boarding school life.

Patron client relationship between kyai, students and people are sturdier in the position of Kyai as significant other in the process of gender construction in boarding school. Relationship pattern patron client among Kyai and students give protection, safety, subsistence, unbalanced, happen in lifetime, reciprocal characteristic, flexible and extend. Social interaction between Kyai and student happened in formal, informal, and non formal. This pattern relationship made students have certain attitude like afraid, shy, and reluctant in interact with Kyai.

\section{SUGGESTION}

Boarding school needs to do socialization about gender to students in Islamic speech activity, learning activity and giving supplement about gender equality in the material to teach. Boarding school needs making forum to examine yellow holy book which is seen from gender equality perception. This 
forum has goal to create theological interpretation that perspective gender. Boarding school should improve the participation of women in education on boarding school through adding the total of woman teacher and work distribution that equal with man and woman. Boarding school also needs adding column in El-Waha magazine and website which contain about examination of gender.

Boarding school needs making forum Musyawarah Majelis Pengasuh that consists of Kyai in boarding school Al-Hikmah Benda 2 , as a forum that makes principle in boarding school.

Boarding school also needs organize communication and discussion forum, and also routine Islamic speech activity among people in boarding school. This activity consists of Kyai, students, and people. This activity has a goal to create social interaction which more intimate among people in boarding school.

\section{REFERENCES}

Irwan, A., 2003. Sangkan paran gender. Pustaka pelajar.

Astuti, T.M.P., 2011. Konstruksi gender dalam realitas sosial. Unnes Press.

Berger, P.L., Parera, F.M. and Luckman, T., 1990. Tafsir sosial atas kenyataan: Risalah tentang sosiologi pengetahuan. $\mathrm{LP}_{3} \mathrm{ES}$

Dhofier, Z., 2011. Tradisi pesantren: Studi pandangan hidup kyai dan visinya mengenai masa depan Indonesia. LP3ES.

Fakih, M., 2008. Analisis gender dan transformasi sosial. Insist Press.

Huda, M., Yusuf, J.B., Azmi Jasmi, K. and Zakaria, G.N., 2016. Understanding Comprehensive Learning Requirements in the Light of alZarnūjî's Ta 'lìm al-Muta 'allim. Sage Open,
6(4), p.2158244016670197.

Istiqomah, N., Doyin, M. and Sumartini, S., 2014. Sikap Hidup Orang Jawa dalam Novel OrangOrang Proyek Karya Ahmad Tohari. Jurnal Sastra Indonesia, 3(1).

Khatimah, Umi Khusnul. 2013. Hubungan Seksual Suami-Istri dalam Perspektif Gender dan $\mathrm{Hu}^{-}$ kum Islam. Jurnal Ahkam. 13(2),pp.235-246.

Marhumah, M., 2012. Konstruksi Gender, Hegemoni Kekuasaan, dan Lembaga Pendidikan. KARSA: Journal of Social and Islamic Culture, 19(2), pp.167-182.

Muchtar, N. and Ritchey, J.A., 2014. Preaching, community, and convergence: Use of old and new media by progressive Indonesian Islamic leaders. International Communication Gazette, 76(4-5), pp.36o-376.

Muslich, M., 2008. Kekuasaan Media Massa Mengonstruksi Realitas. Jurnal Bahasa dan Seni, 36(2), pp.150-159.

Muslich, M., 2008. Kekuasaan Media Massa Mengonstruksi Realitas. Jurnal Bahasa dan Seni, 36(2), pp.150-159.

Muthali'in, A. and Sunanda, A., 2001. Bias gender dalam pendidikan. Universitas Muhammadiyah.

Nafi', M.D., A'la, A., Anisah, H., Aziz, A., Muhaimin, A. 2007. Praksis Pembelejaran Pesantren. Yogyakarta: Intite for Training and Development (ITD) Amherst, MA., Forum Pesantren, dan Yayasan Selasih.

Nurish, A., 2010. Women's Same-sex Relations in Indonesian Pesantren. Gender, Technology and Development, 14(2), pp.267-277

Ritzer, G. and Goodman, D.J., 2004. Teori sosiologi modern. Jakarta: Prenada Media, 121.

Ritzer, G. and Smart, B., 2011. Handbook teori sosial. Bandung: Nusamedia.

Scott, J.C., 1972. Patron-client politics and political change in Southeast Asia. American political science review, 66(1), pp.91-113.

Umar, N. 1999. Kodrat Perempuan dalam Islam. Jakarta: Lembaga Kajian Agama dan Gender, Perserikatan Solidaritas Perempuan, dan The Asia Foundation.

Wahid, A. and Nuriyah, S., 20o1. Wajah Baru Relasi Suami Isteri: Telaah Kitab 'Uqud al-Lujjayn. Yogyakarta: LkiS. 